\title{
Independent Technical Investigation of the Puna Geothermal Venture Unplanned Steam Release, June 12 and 13, 1991 Puna, Hawaii
}

\author{
For: \\ The Honorable Lorraine R. Inouye, Mayor \\ County of Hawaii \\ and \\ The Honorable William W. Paty, Chairperson \\ Board of Land and Natural Resources
}

Prepared by:

Richard Thomas, Dick Whiting, James Moore and Duey Milner

JULY 1991 


\section{DISCLAIMER}

This report was prepared as an account of work sponsored by an agency of the United States Government. Neither the United States Government nor any agency Thereof, nor any of their employees, makes any warranty, express or implied, or assumes any legal liability or responsibility for the accuracy, completeness, or usefulness of any information, apparatus, product, or process disclosed, or represents that its use would not infringe privately owned rights. Reference herein to any specific commercial product, process, or service by trade name, trademark, manufacturer, or otherwise does not necessarily constitute or imply its endorsement, recommendation, or favoring by the United States Government or any agency thereof. The views and opinions of authors expressed herein do not necessarily state or reflect those of the United States Government or any agency thereof. 


\section{DISCLAIMER}

Portions of this document may be illegible in electronic image products. Images are produced from the best available original document. 


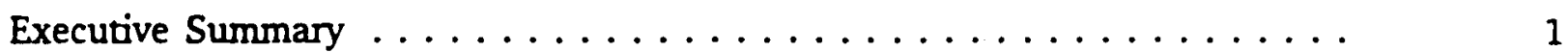

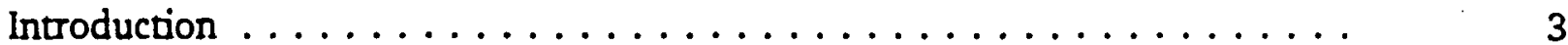

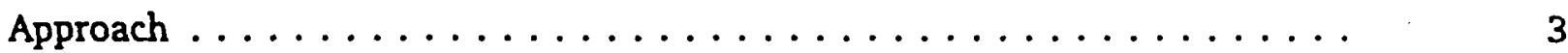

Investigation Team Members ................... 3

Persons interviewed by Investigation Team . . . . . . . . . . .

Geology . . . ........................... 5

Drilling Permits and Inspections ................... 5

General Drilling Program at PGV Location . . . . . . . . . . . . 6

Well KS-7 Blowout Incident . . . . . . . . . . . . . . . 6

Drilling Activities on Well KS-8 Prior To, During, and After the Blowout . . . 6

Well KS-8 Drilling History $\ldots \ldots \ldots \ldots \ldots \ldots \ldots \ldots \ldots \ldots$

Current Status of Well KS-8 . . . . . . . . . . . . . . 10

Analysis of Shallow Subsurface Geologic System

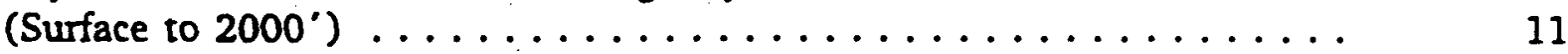

Analysis of the Deep Kick in KS-8 . . . . . . . . . . . . . 11

Analysis of Blowout Equipment $\ldots \ldots \ldots \ldots \ldots \ldots \ldots \ldots \ldots \ldots \ldots$

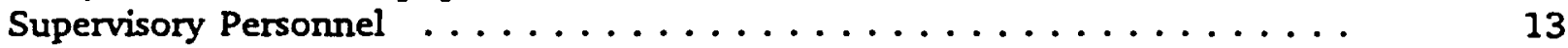

Recommendations ....................... 13

Recommendations for Upper Portion of Well

(Surface to $2000^{\circ}$ ) ......................... 13

$\begin{array}{ll}\text { Recommendations for Equipment Modifications and Additional Equipment . . } & 14\end{array}$

Recommendations for State Regulatory Agencies .............. 15

Recommendations for Supervisory Personnel .............. 16

General Comments on the Permit/Regulatory Process ........... 16

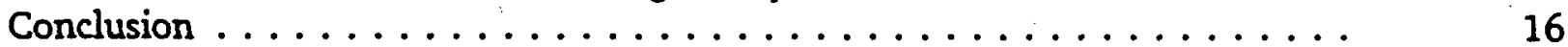

Glossary of Drilling Terms .................... 17

Appendix A - Figures 1 to 10

Appendix B - Drilling History Between May 1, 1991 and June 6, 1991 


\section{EXECUTTVE SUMMARY}

On June 24, 1991, a third-party investigation team consisting of Richard P. Thomas, Duey E. Milner, James L. Moore, and Dick Whiting began an investigation into the blowout of well KS-8, which occurred at the Puna Geothermal Venture (PGV) site on June 12, 1991, and caused the unabated release of steam for a period of 31 hours before PGV succeeded in closing in the well.

The scope of the investigation was to: (a) determine the cause(s) of the incident; (b) evaluate the adequacy of PGV's drilling and blowout prevention equipment and procedures; and (c) make recommendations for any appropriate changes in equipment and/or procedures.

This report finds that the blowout occurred because of inadequacies in PGV's drilling plan and procedures and not as a result of unusual or unmanageable subsurface geologic or hydrologic conditions. While the geothermal resource in the area being drilled is relatively hot, the temperatures are not excessive for modern technology and methods to control. Fluid pressures encountered are also manageable if proper procedures are followed and the appropriate equipment is utilized.

A previous blowout of short duration occurred on February 21, 1991, at the KS-7 injection well being drilled by PGV at a depth of approximately $1600^{\circ}$. This unexpected incident alerted PGV to the possibility of encountering a high temperature, fractured zone at a relatively shallow depth. The experience at KS-7 prompted PGV to refine its hydrological model; however, the drilling plan utilized for KS-8 was not changed.

Not only did PGV fail to modify its drilling program following the KS-7 blowout, but they also failed to heed numerous "red flags" (warning signals) in the five days preceding the KS-8 blowout, which included a continuous 1-inch flow of drilling mud out of the wellbore, gains in murd volume while pulling stands, and gas entries while circulating muds bottoms up, in addition to lost circulation that had occurred earlier below the shoe of the 13-3/8-inch casing.

While there was nothing unusual about encountering a large fracture at a depth of $3476^{\circ}$, especially in light of the drilling experience at $\mathrm{KS}-7$, it was clearly unusual and inappropriate under the circumstances for PGV to be drilling KS-8 at that depth with a mud weight in excess of $10.6 \mathrm{lbs} / \mathrm{gal}$. When the bit encountered the fracture, the heavy drilling mud probably entered the fracture, leaving the well bore partially void of confining fluid, thus allowing steam, gases, etc. from the fractures to enter the well bore, producing the "kick" that led to the blowout.

The decision made by PGV personnel on June 12th to continue to drill to $4000^{\circ}$ before setting 9-5/8" casing should not have been made. The casing string should have been set at $3177^{\circ}$ and cemented to surface in order to seal off the fluids attempting to flow into the well and to serve as a good anchor for additional blowout prevention equipment prior to drilling ahead. 
While not the cause of the blowout, PGV's drilling supervision prior to the kick was inadequate in light of the indications that KS-8 could become a problem well.

PGV personnel took appropriate steps to control the well following the kick. However, there were certain inadequacies in PGV's drilling operations and blowout prevention equipment. The mud cooler being used was inefficient. Monitoring equipment was not strategically placed. A sufficient supply of cold water was not available to pump into the wellbore to properly kill the well in the event of a blowout. The choke line was not of sufficient diameter to handle the volume of fluid that had to be vented, and there was no silencer on the end of the choke manifold line to reduce noise.

The investigation team recommends: (1) substantial changes in PGV's drilling procedures and supervision; (2) several equipment modifications; and (3) significant improvements in regulatory oversight. The investigation team concludes that if the recommendations presented in this report are implemented, drilling geothermal wells in the Kilauea East Rif Zone may proceed safely. This conclusion is limited to the scope of this investigation which pertains only to the technical aspects of geothermal drilling procedures and equipment. 


\section{INIRODUCTION}

On February 21, 1991, a blowout of short duration occurred on the KS.7 injection well being drilled by Puna Geothermal Venture. On June 12, 1991, another more serious blowout occurred on KS-8.

Subsequent to the events, the State of Hawaii and the County of Hawaii requested a special investigation team named below to: (a) determine to the best of the team's ability the cause(s) of the incident; (b) evaluate the adequacy of PGV's drilling and blowout prevention equipment and procedures; and (c) make recommendations for appropriate changes in equipment and/or procedures.

Note: To help the non-technical reader, this report includes a simplified hole circulating system diagram showing monitoring device locations (Fig. 1), a simplified BOPE configuration diagram (Fig. 2), and a glossary.

\section{APPROACH}

The investigation team arrived on the Big Island on the afternoon of June 24, 1991. The team decided to: (1) request and review documents from Puna Geothermal Venture, including but not limited to summary reports, mud logs, tour reports, directional drilling information, and mud reports; (2) interview key personnel and other people with information considered "key"; and (3) visit the site both on the ground and in the air. Because of the short time frame for carrying out the investigation and preparing the report, it was decided not to expand on the team's specific obligations.

In general, Richard Thomas and James Moore took the lead in investigating geologic, hydrologic and permitting aspects, while Duey Milner and Dick Whiting took the lead in investigating drilling procedures, and equipment aspects. All of the team members agree on the contents of the report, which includes information from the many sources.

\section{INVESTIGATION TEAM MEMBERS:}

Richard P. Thomas, Team Leader, Geothermal Officer, State of California Department of Conservation, Division of Oil and Gas

Duey E. Milner, Geothermal Drilling Supervisor, Independent Contractor

James L. Moore, Senior Vice President, Natural Resources, California Energy Company

Dick Whiting, Resource Engineer, State of Nevada, Department of Minerals 
PERSONS INTERVIEWED BY INVESTIGATION TEAM

Maurice A. Richard, Regional Development Manager, Puna Geothermal Venture

Norman J. Clark, Project Manager, Puna Geothermal Venture

William J. Teplow, Field Manager, Puna Geothermal Venture

Terry L. Crowson, Drilling Superintendent, Puna Geothermal Venture

Roger Harrison, Reservoir Engineer, Consultant for Puna Geothermal Venture

Tom Jones, Operations Manager, Parker-Drilling Company

Mark Andrews, Tool Pusher, Parker Drilling Company

Bill Earles, Driller, Parker Drilling Company

John Bishop, Derrickman, Parker Drilling Company

Dale Heriewing, Motorman, Parker Drilling Company

Clement Kalung, Floorman, Parker Drilling Company

J.D. White, Mud Engineer, Baroid

B.J. Livesay, Consultant, Livesay Incorporated

Mike McLaughlin, Mudlogger, Tecton Incorporated (ExLog-Smith)

Eric Tanaka, Geothermal Technician, Department of Land and Natural Resources

Chauncey Hew, Geologist, Department of Health

Jim Kauahikaua, Geophysicist, U.S.G.S.

Richard Moore, Geologist, U.S.G.S.

Frank Truesdell, Geologist, U.S.G.S. 


\section{GEOLOGY}

High temperature geothermal resources are known to be contained within the East Rift system of Kilauea volcano in the Puna area of the Island of Hawaii. Although high temperature geothermal resources may be present within other rift zones on the Big Island and the specific geology of such other rifts zones strongly suggest this, the presence of such resources has not been confirmed by drilling.

The East Rift system of Kilauea is defined as a relatively straight feature extending in a NE by SW direction along the lower seaward flanks of the volcano and extending at least 20 kilometers out to sea.

At the surface, the rift is characterized by a linear expression whose width may vary from one-half to one and one-half miles. Abundant evidence in the form of recent vent deposits, flow rocks, and altered rock within and along the rift, indicates that the rift is plumbed into the Kilauea volcanic system. Eruptive events along its trace tend to cycle every 10 to 15 years and can range from simple, quiet flow events to somewhat explosive vent displays.

Hydrologically, the rift most probably intercepts a large portion of the sub-surface, down-slope water flow. Some water is effectively dammed in its southeasterly flow to the ocean and carried in a northeasterly direction, still down along the hydraulic gradient but parallel to the rift zone. Some of this groundwater undoubtedly finds itself within the plumbing of the rift zone, where it becomes part of the geothermal system.

Within the rift zone, the rocks are generally characterized as volcanic products with divergent modes of origin. It appears that the greatest majority of the rocks are simply extrusive rocks. These rocks have subsequently been intruded by a number of nearvertical, sub-parallel dikes which tend to control the internal movement of fluids, especially in a direction at right angles to the edge of the rift. Given the lateral partitioning, aquifer and reservoir discontinuities are expected within and between the margins of the rift.

\section{DRILING PERMTIS AND INSPECTIONS}

Geothermal Well Drilling Permits for production wells in Hawaii are issued by the Department of Land and Natural Resources (DLNR). The Department of Health (DOH) issues an Authority to Construct Permit for both production and injection wells, in addition to a letter of approval to construct dedicated injection wells. In all cases, the operator submits a proposed drilling program to the respective agencies, which includes information the agencies need to show that regulations are and will be met. Included in the DLNR regulations are a description of casing strings and setting depths, and required Blowout Prevention Equipment (BOPE) for various drilling scenarios. 
In wells KS-7 and KS-8, which were originally proposed as injection wells, the DOH issued the permits to drill, had authority to allow casing changes, but did not have a trained inspector in the field to make drilling observations.

On the other hand, an inspector for DLNR typically visited the PGV site daily and recorded drilling observations, but had no authority to approve changes in operations.

At the time of the KS-8 incident, DLNR was reviewing a proposal submitted by PGV to complete the well as a production well.

\section{GENERAL DRILING PROGRAM AT PGV LOCATION}

In the general drilling program, a 26-inch hole is drilled without BOPE from about $60^{\circ}$ to approximately $1200^{\circ}$ and cased. A $17-1 / 2$-inch hole is drilled to $\left(2000^{\circ}-2200^{\circ}\right)$, passing through an unconfined aquifer, containing fresh water naturally contaminated by an underlying geothermal system. Blowout protection is provided by an annular preventer and a diverter (Fig. 3). The well is then cased at about $2000^{\circ}$.

According to the "Production and Injection Well Casing Monitoring Program" submitted by PGV to DOH on April 28, 1991, a zone between $2000^{\prime}$ and $2600^{\prime}$ serves as an effective aquitard separating the high temperature zone from the low temperature zone. Locally, the aquitard may be breached as in the area of injection well KS-7 (Note: This well experienced a blowout incident and is described below.) and monitor well GTW III where anomalously high shallow groundwater temperatures and salinities are observed.

\section{WELL KS-7 BLOWOUT INCIDENT}

On February 21, well KS-7 was drilled through an intensely mineralized zone, had minor mud flow returns during connections below 1500', and blew out at 1678', injuring a righand. The driller quickly closed the annular preventer, and vented fluid out a 3-inch diverter, before closing the diverter and securing the well. At the time of the incident, the annular preventer, which was secured to $13-3 / 8$-inch casing cemented at $1020^{\circ}$, served as the sole BOPE. The well was subsequently plugged and suspended. According the Puna's proposal, flow into the hole was not anticipated to occur at this relatively shallow depth.

\section{DRILING ACTIVTTIES ON WELL KS-8 PRIOR TO, DURING, AND AFTER THE BLOWOUT}

\section{Well KS-8 Drilling History}

Subsequent to suspending KS-7 and working over KS-1A, PGV moved onto the KS-8 wellpad and commenced to directionally drill injection well KS-8 in the direction of KS-7 (See Fig. 4). The drilling history for KS-8 for the dates May 1, 1991 through June 
6, 1991 is located in Appendix B. The following history starts on June 7, 1991 and has been assembled mainly from information shown on tour reports, the drilling history, and other reports supplied by PGV, as well as from information gathered in a series of interviews held with involved personnel (Note: All temperatures are in degrees Fahrenheit):

It should be noted that on June 7,1991 , the casing condition of the hole was as follows: 30 -inch casing cemented from $70^{\circ}$ to surface; 20 -inch casing cemented from $1032^{\prime}$ to surface; $13-3 / 8$-inch casing cemented from $2128^{\circ}$ to surface; 12-1/4-inch open hole to $3177^{\circ}$. Blowout prevention was provided by the BOPE stack shown on Figure 5 . Prior to this date, mud temperature in was less than $130^{\circ}$, mud temperature out less than $135^{\circ}, \mathrm{CO}_{2}-300 \mathrm{ppm}$, and $\mathrm{H}_{2} \mathrm{~S}-0 \mathrm{ppm}$.

06-07-91: Drilled and surveyed from $3177^{\circ}$ to $3401^{\circ}$, pulled out of hole, picked up mud motor, ran in hole, attempted to drill, pulled out of hole 15 stands. At 9:15 am the flow line temperature was $172^{\circ}$.

06-08-91: Well started to flow, ran back to bottom, gained 16 barrels (bbls) of mud, circulated and built mud weight to $10.4 \mathrm{lbs} / \mathrm{gal}$. (ppg), spotted heavy mud weight on bottom (11.2 ppg). Pulled out of hole with mud motor, well flowing 1-inch stream. Ran in hole open-ended, circulated at $1054^{\circ}, \operatorname{ran}$ to $2079^{\circ}$, circulated.

06-09-91: Ran to $2725^{\circ}$, circulated, $\operatorname{ran}$ to $3401^{\circ}$, circulated. During circulation, mud temperature in was less than $132^{\circ}$, mud temperature out was less than $146^{\circ}$. Bottoms up at $3400^{\circ}$, mud temperature out $205^{\circ}, \mathrm{CO}_{2}$ 330-5600 ppm, $\mathrm{H}_{2} \mathrm{~S}-80 \mathrm{ppm}$. Rigged up Halliburton (cementing company), cemented with 50 sacks of Hawaii cement, pulled 3 stands, well was flowing. Waited on cement. Ran in hole, tagged cement at $3298^{\circ}$. Rigged up Halliburton, pumped 28 sacks cement. Pulled out of hole with drill pipe, picked up drilling assembly ran in hole on top of cement at $3151^{\circ}$. During circulation mud temperature in was less. than $148^{\circ}$, mud temperature out was less than $147^{\circ}$. Bottoms up at $3151^{\prime}$, mud temperature out $209^{\circ}, \mathrm{CO}_{2}-330-10,300 \mathrm{ppm}, \mathrm{H}_{2} \mathrm{~S}-190$ ppm.

06-10-91: Drilled cement from $3151^{\circ}$ to $3350^{\circ}$, well flowing (1-inch stream). Pulled out of hole with drilling assembly, ran in hole open-ended to $3350^{\circ}$. During circulation mud temperature in was less than $137^{\circ}$, mud temperature out was less than $162^{\circ}$. Bottoms up at $3350^{\circ}$, mud temperature out $189^{\circ}, \mathrm{CO}_{2}-330-780 \mathrm{ppm}, \mathrm{H}_{2} \mathrm{~S}-0-10 \mathrm{ppm}$. Rigged up Halliburton, pumped 50 sacks of cement spotted on bottom, pulled up to $2135^{\circ}$, circulated at $3140^{\circ}$, pumped 35 sacks of cement, spotting on bottom. Pulled 5 stands. Closed pipe ram, squeezed away 3 bbls at 300 psi. Opened rams, pulled out of hole. 
06-11-91: Picked up drilling assembly and ran in hole to $2060^{\circ}$, waited on cement, and circulated, ran in hole to top of cement at $2845^{\circ}$, drilled cement to $3350^{\circ}$, circulated hole, pulled 8 stands, gained 20 bbls. mud in pits, $\operatorname{ran}$ in hole to bottom at $3350^{\circ}$, circulated and cooled hole. During circulation, mud temperature in was less than $148^{\circ}$, temperature out was less than $169^{\circ}$. Bottoms up at $3350^{\circ}$, mud temperature out $164^{\circ}$.

Note: According to the "Geothermal Well KS-8 Uncontrolled Flow Event and Well Design Review", made available to the investigation team by PGV, a meeting took place at the PGV office in the afternoon of June 12. Attendees were project and drilling personnel. Interviews conducted by the investigation team substantiated that the meeting resulted in the following decisions:

"It was decided that PGV would elect to drill deeper in order to set the 9-5/8-inch casing in the well at a depth nearer to $4000^{\circ}$ as originally detailed in the well prognosis. It was decided to drill out the cement in the bottom of the well after circulating bottoms up at $3350^{\circ}$. It was decided to maintain a mud weight of 10.5 ppg in circulating botroms up and to drill ahead with this mud weight. It was also decided to make Maximum Recording Temperature (MRT) runs inside the drill pipe at every stand after drilling recommenced. It was planned to plot the MRT data on the temperature graphs and by means of this data to ascertain when to run the 9-5/8-inch casing."

6-12-91: Checked for flow, 1-inch stream to pits, pulled out of hole, rigged up loggers to run temperature logs. (Note: The 1-inch stream could be caused by heat expansion.) Ran temperature logs and all failed with no results, rigged down loggers, picked up drilling assembly, $\operatorname{ran}$ in hole to $3350^{\circ}$. Circulated bottoms up at $3350^{\circ}$, mud temperature out $165^{\circ}, \mathrm{CO}_{2}-9350$ ppm, $\mathrm{H}_{2} \mathrm{~S}-83 \mathrm{ppm}$. Drilled cement from $3350^{\circ}$ to $3401^{\circ}$. Drilled new formation from $3401^{\circ}$ to $3488^{\circ} \pm$. Mud temperature at $3450^{\circ}, 129^{\circ}$ in, $151^{\circ}$ out. Mud temperature at $3480^{\circ}, 128^{\circ}$ in $150^{\circ}$ out. Driller drilled into large fracture, starting a sequence of events which led to the blowout. Well unloaded. Mud temperature recorded at $3488^{\circ}, 111^{\circ}$ in, $260^{\circ}+$ out.

Indications to the driller were that pump pressure was increasing. The mudlogger was on the way up to the rig floor when he noticed that fluid was coming over the shale shaker. The driller was picking up the kelly to close the BOPE's when the well unloaded at about 11:16 pm.

The following describes the conditions found and the sequence of events and actions taken during the kick and uncontrolled flow:

06-12-91: 1. The rotating head that was nippled up on the top of the BOPE stack was destroyed at the time of the first kick. 
2. The annular preventer (Hydril) was damaged and the packing element ruptured by the excessive pressure impulse of the gas. The Hydril was made inoperative.

3. The driller was forced away from the brake due to the excessive steam that engulfed the area at the time of the kick and the floor plate buckled around the driller's console. As a result, the kelly dropped into the area of the pipe ram closure. The driller then closed the upper rams around the kelly. Pipe rams will not close completely around the hexagonal kelly, therefore, there was leakage around the kelly which prevented the crew from being able to work on the floor. The rig floor was engulfed in steam.

4. The location was cleared and all personnel were accounted for.

5. Agencies and PGV personnel were notified.

6. The following decisions were made to:

a. Shut down electric power to the rig drawworks at the Silicon Controlled Rectifier (SCR) panel.

b. Move the safety trailer from the site to a location above the site and away from the wellhead.

c. Wait until daylight to reassess the situation and to take other actions around the rig and on the rig floor.

7. Personnel with safety gear moved the safety trailer from the site to a location above the site and away from the wellhead.

06/13/91: 8. At dawn (6:00 am) the Hydraulically Controlled Relief $(H C R)$ valve was opened, venting the well through the choke manifold and the leakage around the kelly in the pipe rams.

9. It was at this point that it became known that:

a. The Hydril was inoperative.

b. The damage to the kill line and to the mud line had caused the pumps to pump onto the drill site and not down the drill pipe. The mud pits were dry.

c. The bottom metal pipe rams and the upper blind rams were still open. 
10. It was decided to mobilize Halliburton to pump cold water down the drill pipe.

11. Parker crews nigged the Halliburton cementing lines to the standpipe and closed the lower valve to the fill-up line. This established the path to pump fluids down the drill pipe.

12. Halliburton was rigged to pump down the drill pipe through cementing lines. (10:30 am)

13. Closed in the choke line. Pumped water at $9.5 \mathrm{bbls} / \mathrm{min}$. Pressure at 1700 psi decreasing to 900 psi. Bottom pipe rams closed.

06/14/91: 14. Rigged up lines to Halliburton to pump down the annulus. Pumped $5 \mathrm{bbls} / \mathrm{min}$. down the annulus. Initial pressure at $1700 \mathrm{psi}$ reducing to 1000 psi. Pumped down the drill pipe at $4 \mathrm{bbls} / \mathrm{min}$., pressure still at 900 psi $(4: 00 \mathrm{am})$.

15. Pumped lost circulation material (LCM) to plug off steel pipe rams. Flow was controlled. (10:00 am)

16. Changed out the top pipe rams. Steel rams with LCM held.

Figure 6 shows the casing diagram of KS-8 effective June 23, 1991 and diagramed by PGV.

Figure 7 shows the static temperature and pressure profiles recorded on surveys run June 21, 1991. At the time of the survey, water was being injected in the casing/drill pipe annulus at $3 \mathrm{bbls} / \mathrm{min}$. The graph of KS-8 suggests that geothermal fluids at about $633^{\circ}$ and 1950 psi are entering the wellbore near $3488^{\circ} \pm$ and flowing up the wellbore and into fractures below the shoe of the 13-3/8-inch casing at 2128'.

\section{CURRENT STATUS OF WELL KS-8}

At the time of preparation of this report, steam flow from the well has stopped and the control of wellhead pressure is being maintained by the use of low volume water injection into the wellbore. However, complete "killing" of the well, defined as the elimination of all heat and pressure at the wellhead, either by means of heavy mud, cement, or high volume pumpage of water, has not been achieved. The well is being cooled by the injection of water, and the down-hole temperatures and pressures are decreasing. Surface pressure measured at the wellhead is 5 psi. Planning and preparation work is currently underway to determine the appropriate procedure for killing the well. Once the well is killed, PGV plans to set cement plugs at the appropriate depths to seal off fluid entries near the bottom of the hole and the lost circulation zone just below the 
shoe of the 13-3/8-inch casing. PGV has indicated that after the well is killed and total control is established, the well will be secured for further evaluation.

\section{ANALYSIS OF SHALLOW SUBSURFACE GEOLOGIC SYSTEM (Surface to 2000')}

In a subsurface geologic system such as may occur in the rift zone, the presence of vertical cracks intercepting largely horizontal basalt layers may allow locally for the existence of high temperature fluids and high pressure at relatively shallow levels.

It appears that the shallow blowout experience on KS-7 led to a refinement of the PGV's hydrological model. The possibility of a breached aquitard is discussed in the April 1991 document submitted by PGV to DOH.

In spite of new information suggesting the existence of a shallow system, the drilling program was not changed for KS-8, due to the belief that conditions were different and more typical of conditions encountered in previously drilled wells. KS-8 was successfully drilled to $2000^{\circ}$ without incident.

\section{ANALYSIS OF THE DEEP KICK IN KS-8}

One explanation of the conditions which KS-8 encountered is as follows:

The temperature and pressure measurements in KS-8 (See Fig. 7), taken after-thefact, indicate greater temperatures and pressures with depth than the maximum temperatures and pressures which were expected based on water/steam pressure and temperature phase change projections. The anomalous temperatures and pressures can be explained on the basis that the drill bit encountered a hydrologically balanced, subvertical fracture which when opened by the bit, enabled the deeper (stable at the deeper, higher pressure reservoir) liquids to move to a higher level. Once the pressure on the deeper water was reduced, the liquids flashed into steam and hence violently vented through the hole toward the surface.

An alternative explanation could be that as part of the Kilauea inflation and deflation cycle, magma could have recently been emplaced at a relatively higher level beneath the reservoir providing the mechanism for increasing the pressure and temperature of the reservoir.

There were numerous "red flags" (warning signals) in the 5 days preceding the blowout, such as a continuous 1-inch flow of drilling mud out of the wellbore, gains in mud volume while pulling stands, and gas entries while circulating bottoms up, in addition to lost circulation that had occurred earlier below the shoe of the 13-3/8-inch casing. 
The decision to drill to a depth of $4000^{\circ}$ should not have been made. With all of the "red flags" that were noticed during the drilling of KS-8 from the shoe of the 13-3/8inch casing cemented at a depth of $2128^{\circ}$ to $3177^{\circ}$, it is our opinion that the 9-5/8-inch casing string should have been set at $3177^{\circ}$ and cemented to surface in order to control and isolate the problem behind casing and allow a good anchor for BOPE prior to further drilling.

Any flow from the well bore of a geothermal well being drilled that cannot be controlled or stopped indicates that there is a serious problem down hole. The first line of defense against a blowout, the hydrostatic head of the drilling fluid column, is diminished with any type of uncontrolled flow. Whether the flow is being caused by temperature or pressure from down hole makes little or no difference. Either cause creates a problem.

There was nothing unusual about encountering a large fracture at $3476^{\circ}$. The unusual situation was that the mud column in the hole was in excess of $10.6 \mathrm{ppg}$. When the bit encountered the fracture, the heavy drilling mud probably entered the fracture, leaving the well bore partially void of confining fluid, thus allowing steam, gases, etc. from the fractures to enter the well bore.

Kicks in geothermal wells are usually controlled with the use of cold or cool water. Rarely or never in the panel's experience has weighted mud been used to control a geothermal kick. This is why it is recommended to have a large supply of cold or cool water on location and a pump system capable of delivering it to the intended zone.

\section{ANALYSIS OF BLOWOUT EQUTPMENT}

The following observations were made of the existing BOPE.

1. It was reported to us that the mud cooler that is being used on this well only cools the mud some $10^{\circ}$. Also, it was necessary to shut it down for cleaning with each drill pipe connection. It is not an efficient mud cooler.

2. It was reported by the driller that the mud pump \#2 was being operated at 90 to 100 strokes per minute (spm) with 6-inch liners. The mud pumps should have been pumping a minimum of $150 \mathrm{spm}$ with this liner size (6") for that diameter hole $\left(12-1 / 4^{\prime \prime}\right)$.

3. The pit level indicators and other monitoring equipment on the rig were not in strategic places for the driller to observe. The pit alarm system was hooked up only in the Exlog mud logger's trailer. This made it necessary for the driller to wait to hear from the mud logger to find out that there was a problem developing. If the mud logger was not in his trailer at the time of an alarm, more time would be lost. Time is a very important factor in controlling kicks. 
4. It has been noted that the fresh water supply at this location is at least $100^{\circ}$. Geothermal wells that kick can and have been easily controlled by pumping large volumes of cool or cold water into the well bore. A source with a temperature less than $75^{\circ}$, such as ocean water, could be used.

5. From all of the reports, both written and oral, it was evident the choke line was not of sufficient diameter to handle the volume of fluid that had to be vented from the well at the time of the kick. Also the 4-inch valve on the choke line had to be manually opened. The time involved in opening the 4inch valve is critical when taking a kick of this magnitude.

6. At the time of this kick there was no silencer or muffler on the end of the choke manifold line, which caused a great deal more noise than necessary.

\section{SUPERVISORY PERSONNEL}

It has been reported that approximately ten minutes before the blowout occurred, both the drilling supervisor and the toolpusher left the floor to go to their trailers, leaving the driller alone on the floor drilling a well that had for almost a week been showing signs of becoming a problem well. This was also just prior to a crew change.

\section{RECOMMENDATIONS}

Effective, safe and efficient geothermal exploration requires that both regulators and operators conceptually understand the complexities of a geothermal system. They must understand that the subsurface conditions varies from well-to-well and in fact may, with time, change within an individual well. The decision process of the operator and his communications with the appropriate regulatory body(ies) must be based on this kind of understanding. Specific parameters for well design and possible modification during drilling must be made on a well-by-well basis, often as demanded by the subsurface conditions encountered during the drilling process. The mechanism to accomplish such a process must be timely and safe.

\section{RECOMMENDATIONS FOR UPPER PORTION OF WELl (Surface to 2000')}

Additional precautions should be taken to assure that blowout prevention equipment is maximized in case high temperature geothermal fluids are encountered at depths well above the currently modeled depths. We recommend that:

1. The operators be conservative and flexible in their approach to casing the well above $2000^{\circ}$. 
2. If the operator must drill below $500^{\circ}$ without BOPE, he should:

a. Run maximum bottom hole temperatures every connection, looking for an increase in thermal gradient,

b. Take representative water samples and have them analyzed as soon as possible to monitor increases in salinity and conductivity, and

c. Catch cutting samples every $10^{\circ}$ and analyze them for the presence of hydrothermal minerals.

If it appears that a geothermal zone may be encountered soon, the operator with approval of the DLNR, should be prepared to run casing, cement, and rig up with appropriate blowout protection.

\section{RECOMMENDATIONS FOR EQUIPMENT MODIFICATIONS AND ADDITIONAL EQUIPMENT}

There are six areas of equipment modification which, if they had been made prior to the KS-8 event, may have prevented the blowout. Given the high temperatures of this resource, we recommend that the following modifications be made:

1. There is a need for a larger flow relief from the BOPE stack. This would prevent damage to the well control equipment, allowing the flow to be diverted safely and rapidly away from the rig floor. The relief line should have a low pressure burst plate to automatically divert the flow so that the crew is able to secure the well. In addition to a larger diverter line which should be 13-3/8-inch in diameter, an additional double gate preventer should be included in the stack (See Fig. 8).

2. At the discharge end of this 13-3/8-inch diverter line a silencer or muffler should be installed. This piece of equipment would greatly reduce the noise factor if it becomes necessary to divert any flow from the well.

3. The mud pumps should be equipped with the maximum sized pump liners, and should be used when attempting to control a kick, at maximum stroke.

4. Facilities for a cool water supply, sufficient to kill a kick in a large diameter hole such as KS-8, must be on location at all times while drilling.

5. The present mud cooling system is inadequate to properly cool the drilling fluid for wells such as KS-8. Either a larger mud cooler or the addition of another mud cooler to the system should be required. 
6. A monitoring device should be installed for the driller. This would give the driller quicker information regarding any downhole pressures and changes. A pit alarm system should be included with this monitoring device. This would give the driller a chance to react to any changes and allow the crew to operate the blowout prevention equipment that is available to secure the well.

Figures 9 and 10 show two BOPE stack arrangements which may be appropriate for future drilling activities at the PGV site. It is recommended that they be considered by the operator and DLNR prior to resumption of operations. It should be noted that PGV has already provided the investigation team with a plan for upgrading equipment and procedures, which includes some of the same recommendations.

\section{RECOMMENDATIONS FOR STATE REGULATORY AGENCIES}

There are five recommendations that we suggest for improving regulatory oversight on geothermal projects:

1. The situation that currently exists where there appears to be insufficient involvement of DLNR on injection wells should be resolved. DLNR and DOH must come to an agreement to jointly provide oversight and regulatory control to the drilling of all wells, regardless of whether they are intended as injection wells or production wells. One possibility is for the agencies to enter into a Memorandum of Agreement providing for DOH lead status in Underground Injection Control (UIC) review and DLNR lead status in drilling program review and inspection for all wells.

2. Drilling into a fractured reservoir requires flexibility on the part of the operators and regulators, coupled with extreme vigilance on the part of the operators, because fluids and pressure may be found at depths not predicted. beforehand. There should be a mechanism in the regulator/operator relationship whereby the operator is permitted to make judgement calls to modify his casing program or drilling operations as required, and the regulatory agency should be prepared to accept, amend, or deny the proposal in a timely manner.

3. DLNR should be more involved in the casing approval process regardless of whether the well is an injection or production well. The casing program should be reviewed on a well-to-well basis, incorporating accumulated knowledge of the system. DLNR should also make sure that they are advised of any changes in the model of the reservoir, and should concurrently be developing their own model. 
4. DLNR should minimize specific BOPE and casing requirements in the administrative regulations. Specific descriptions of BOPE and procedures could be placed in a manual and updated regularly. DLNR should allow flexibility in its requirements for BOPE and casings. These requirements should allow for modifications during drilling on a case by case basis, subject to local variations in geology and reservoir conditions.

5. The State of Hawaii should contact the National Geothermal Drilling Organization (NGO) and the American Society of Testing of Materials (ASTM), ask for a review of current operations, and work toward establishing equipment and procedures standards for drilling geothermal wells in the state.

\section{RECOMMENDATIONS FOR SUPERVISORY PERSONNEL}

It is necessary for supervisory personnel to be present on the rig floor while all drilling is taking place and especially during crew tour changes to be sure the crew coming on tour is instructed and advised of any special instructions. We understand that blowout prevention drills were performed on this drilling operation prior to the June 12th incident. All blowout prevention drills and operations of BOPE should be noted on the A.I.D.C. tour reports. Also, all toolpushers, drillers, and derrickmen should be schooled in the use of the recommended monitoring equipment.

\section{GENERAL COMMENTS ON THE PERMTT/REGULATORY PROCESS}

1. The regulatory people appear to be qualified and committed, as well as sensitive to the local concerns.

2. The project technical people appear to be technically qualified, committed to the project and sensitive to the concerns of their employees.

\section{CONCLUSION}

The blowout of KS-8 might have been avoided if PGV had paid heed to wamings which the well was signalling for several days prior to the kick. Once having occurred, the uncontrolled steam release could have been minimized had the necessary equipment and an adequate supply of cold water been available. The investigation team concludes that if the recommendations presented in this report are implemented, drilling of geothermal wells in the Kilauea East Rift Zone may proceed safely. This conclusion is limited to the scope of this investigation which pertains only to the technical aspects of geothermal drilling procedures and equipment. 


\section{GLOSSARY OF DRILIING TERMS}

ACCUMULATOR - A pressure vessel, precharged with a compressed gas above a movable barrier, used to store hydraulic fluid under pressure.

ACCUMULATOR UNIT - (Actuating Unit, Closing Unit) - A compact assembly of pumps, valves, accumulators, and other items used to maintain and restore the volume of working fluid needed to operate the preventers.

ACTUATING SYSTEM - (Operating and Control System) - The entire array of equipment that provides and controls the hydraulic fluid needed to operate the preventers. Consists of the accumulator unit and emergency backup system, the control manifold and remote station, and the hydraulic lines to the preventers.

ANCHOR STRING - The string of casing to which the BOPE stack is flanged.

ANNULAR PREVENTER - (Bag Preventer) - A device that can seal around almost any object in the well bore or upon itself. Compression of a reinforced elastomer packing element by hydraulic pressure effects the seal.

ANNULAR SPACE OR ANNULUS - The space surrounding a cylindrical object within a cylinder. The space around a pipe in a wellbore, the outer wall of which may be the wall of either the borehole or the casing; sometimes termed the annulus.

AQUITARD - A confining bed that retards but does not prevent the flow of water to or from an adjacent aquifer.

$\underline{B O P}$ - See Blowout Preventer.

BOPE - See Blowout Prevention Equipment.

BANJO BOX - A thick-walled drilling spool used when drilling with air. The spool routes returning air and drill cuttings to a blooie line.

BELL NIPPLE - (Flow Nipple, Mud Riser) - A piece of pipe with an inside diameter equal to or greater than the blowout preventer bore. It is connected to the top of blowout preventer or marine riser. A side outlet directs the mud returns to the shale shaker or pit. It usually has a second side outlet for fill-up line connection. 
BLIND RAMS - (Blank, CSO, Complete.Shut Off, Master) - Rams that are not intended to seal against any drilling pipe or casing. They seal against each other to effectively close the hole. See Ram-Type Preventer.

BLIND-SHEAR RAMS - Blind rams with a built-in cutting edge that will shear pipe in the hole, allowing the blind rams to seal the hole. Used primarily in subsea systems.

BLOOIE LINE - A large-diameter pipe that routes returning air and drill cuttings to a muffler. The line is equipped with high pressure nozzles that both spray water to settle dust and spray sodium hydroxide and hydrogen peroxide to eliminate hydrogen sulfide odors.

BLOWOUT - An uncontrolled flow of well fluids and/or formation fluids from the well bore to the surface, or into lower-pressured subsurface zones (underground blowout).

BLOWOUT PREVENTER (BOP) - A device attached to a casinghead that allows the well to be sealed to confine the well fluids in the well bore.

BLOWOUT PREVENTER DRILL - A training procedure to determine that rig crews are completely familiar with the correct operating practices to be followed in the use of blowout prevention equipment. A "dry run" of blowout prevention action.

BLOWOUT PREVENTER STACK - The assembly of well-control equipment including preventers, spools, valves, and nipples connected to the top of the casinghead.

BLOWOUT PREVENTION EOUIPMENT - The entire array of equipment installed at the well to control kicks and prevent blowouts. Consists of the preventers, actuating system, and auxiliary equipment.

CSO RAMS - See Blind Rams.

CASINGHEAD/SPOOL - The part of the wellhead to which the blowout preventer stack is connected.

CASING STRING - The entire length of all the joints of casing run in a well. Casing is manufactured in lengths of about 30 feet, each length or joint being joined to another as casing is run in a well.

CHOKE - A device with a fixed or variable aperture used to control the flow rate of liquids and/or gas. 
CHOKE LINE - That segment of auxiliary equipment designed to control and direct the flow of fluids from the well bore. Consists of the control valve, the choke manifold, and all piping from the control valve to the manifold and from the manifold to the fluid storage system.

CHOKE LINE VALVE - See Control Valve.

CHOKE MANIFOLD - An assembly of valves, chokes, gauges, and lines used to control the rate of flow from the well when the blowout preventers are closed.

CONDUCTOR PIPE - A short string of pipe set to cover unconsolidated surface formations, and to control fluid returns. Usually cemented.

CONTROL VALVE - The valves connected to the BOPE stack which regulate fluid access from the kill line to the well bore and from the well bore to the choke line.

DERRICKMAN - The crew member who handles the upper end of the drill stem as it is being hoisted out of or lowered into the hole. He is also responsible for the conditioning of the drilling fluid and the circulating machinery.

DIVERTER - A device attached to the wellhead or marine riser to close the vertical access and direct any flow into a line away from the rig. It differs from blowout preventers in that flow is not stopped, just redirected away from the rig.

DRAWWORKS - The hoisting mechanism on a drilling rig. It is essentially a large winch that spools off or takes in the drilling line and thus raises or lowers the drill stem and bit.

DRILLER - The employee directly in charge of a drilling rig and crew. His main duty is operation of the drilling and hoisting equipment, but he is also responsible for the downhole condition of the well, operation of downhole tools, and pipe measurements.

DRILL STRING FLOAT - A check valve, run as an integral part of the pipe string, that allows fluid to be circulated down the drill string, but will prevent backflow.

DRILLING SPOOL - A connection component with both ends either flanged or hubbed. It must have an internal diameter at least equal to the bore of the blowout preventer and can have smaller side outlets for connecting auxiliary lines.

EMERGENCY BACKUP SYSTEM - An accessory to the accumulator unit which provides an independent source of energy to operate the preventers. 
FILL-UP LINE - A line, usually connected into the bell nipple above the blowout preventers, that allows the addition of mud to the hole while pulling out of the hole, in order to compensate for the displacement of the drill string.

FLOORMAN - A drilling crew member whose work station is on the derrick floor. On rotary drilling rigs, there are at least two and usually three or more floormen on each crew. Also called rotary helper and roughneck.

FLOW LINE - A line connecting the well bore to the hole fluid storage or processing area.

GATE VALVE - A valve utilizing a sliding gate to open or close the flow passage. May or may not be full opening.

HOLE FLUID MONITORING EOUIPMENT - BOPE accessories which indicate or record information concerning the hole fluid system, such as volume of fluid used, presence or absence of fluid, and changes in the volume or physical characteristics of the fluid.

INSIDE BLOWOUT PREVENTER - See Internal Preventer.

INTERNAL PREVENTER - A device, which acts as a check valve, that can be installed in the drill string. It allows fluid to be circulated down the drill string but prevents back flow.

KELLY - The heavy steel member, four- or six-sided, suspended from the swivel through the rotary table and connected to the topmost joint of drill pipe to turn the drill stem as the rotary table turns. It has a bored passageway that permits fluid to be circulated into the drill stem and up the annulus, or vice versa.

KELLY COCK, LOWER - A full opening valve installed immediately below the kelly, with outside diameter equal to the tool joint OD. Can be closed to remove the kelly under pressure, and can be stripped into the hole for snubbing operations.

KELLY COCK, UPPER - A valve immediately above the kelly that can be shut to confine pressures inside the drill string. 
KICK - The intrusion of formation liquids or gas that results in an increase in pit volume. Without corrective measures, this can result in a blowout.

KILL LINE - A high pressure line between the pumps and some point below a blowout preventer that allows fluids to be pumped into the well or annulus when the preventer is closed.

LOG - A systematic recording of data, as from the driller's log, mud log, electrical well $\log$, or radioactivity log. Many different logs are run in wells being produced or drilled to obtain various characteristics of downhole formations.

LOST CIRCULATION - The loss of quantities of whole mud to a formation, usually in cavernous, fissured, or coarsely permeable beds, evidenced by the complete or partial failure of the mud to return to the surface as it is being circulated in the hole.

LOST RETURNS - Loss of drilling fluids into the formation, resulting in a decrease in pit volume.

MOTORMAN - The crew member on a rotary drilling rig responsible for the care and operation of drilling engines.

MUD LOGGING - The recording of information derived from examination and analysis of formation cuttings made by the bit and mud circulated out of the hole. A portion of the mud is diverted through a gas-detecting device. Mud logging is often carried out in a portable laboratory set up at, the well to examine cuttings brought up by the mud.

MUD-RETURN LINE - A trough or pipe placed between the surface connections at the wellbore and the shale shaker, through which drilling mud flows upon its return to the surface from the hole.

MUD WEIGHT RECORDER - A graphical display of the input from the instrument in the mud system which continuously measures mud density.

PACKOFF or STRIPPER - A device with an elastomer packing element that depends on pressure below the packing to effect a tight seal in the annulus. Used primarily to run or pull pipe under low or moderate pressures. Cannot be depended upon under high differential pressures. 
PIPE RAMS - Rams with faces contoured to seal around pipe to close the annular space. Unless special rams accommodating various pipe sizes are used, separate rams are necessary for each pipe size in use. See Ram-Type Preventer.

PIT LEVEL INDICATOR - A device installed in the mud tank to register the fluid level in the tank.

RAM-TYPE PREVENTER - A device that seals the open space in the well bore by forcing two horizontal sliding gates (rams) against one another. See Blind Rams or Pipe Rams.

$\underline{R I G}$ - The derrick or mast, drawworks, and attendant surface equipment of a drilling unit.

ROTATING HEAD - A rotating, pressure-sealing device used when drilling with air, gas, foam, or any other drilling fluid with hydrostatic pressure less than the formation pressure.

SETTING CASING - To run and cement casing at a certain depth in the wellbore. Sometimes, the term "set pipe" is used when referring to setting casing.

SHALE SHAKER - A series of trays with sieves that vibrate to remove cuttings from the circulating fluid in rotary drilling operations. The size of the openings in the sieve is carefully selected to match the size of the solids in the drilling fluid and the anticipated size of cuttings. Also called a shaker.

SLAB GATE VALVE - A mechanical, positive-sealing device that is used as a master valve on geothermal well heads.

STANDPIPE - A vertical pipe rising along the side of the derrick or mast, which joins the discharge line leading from the mud pump to the rotary hose and through which mud is pumped going into the hole.

SWABBING - The lowering of the hydrostatic pressure in the hole resulting from the upward movement of pipe and/or tools. 
APPENDIX A 


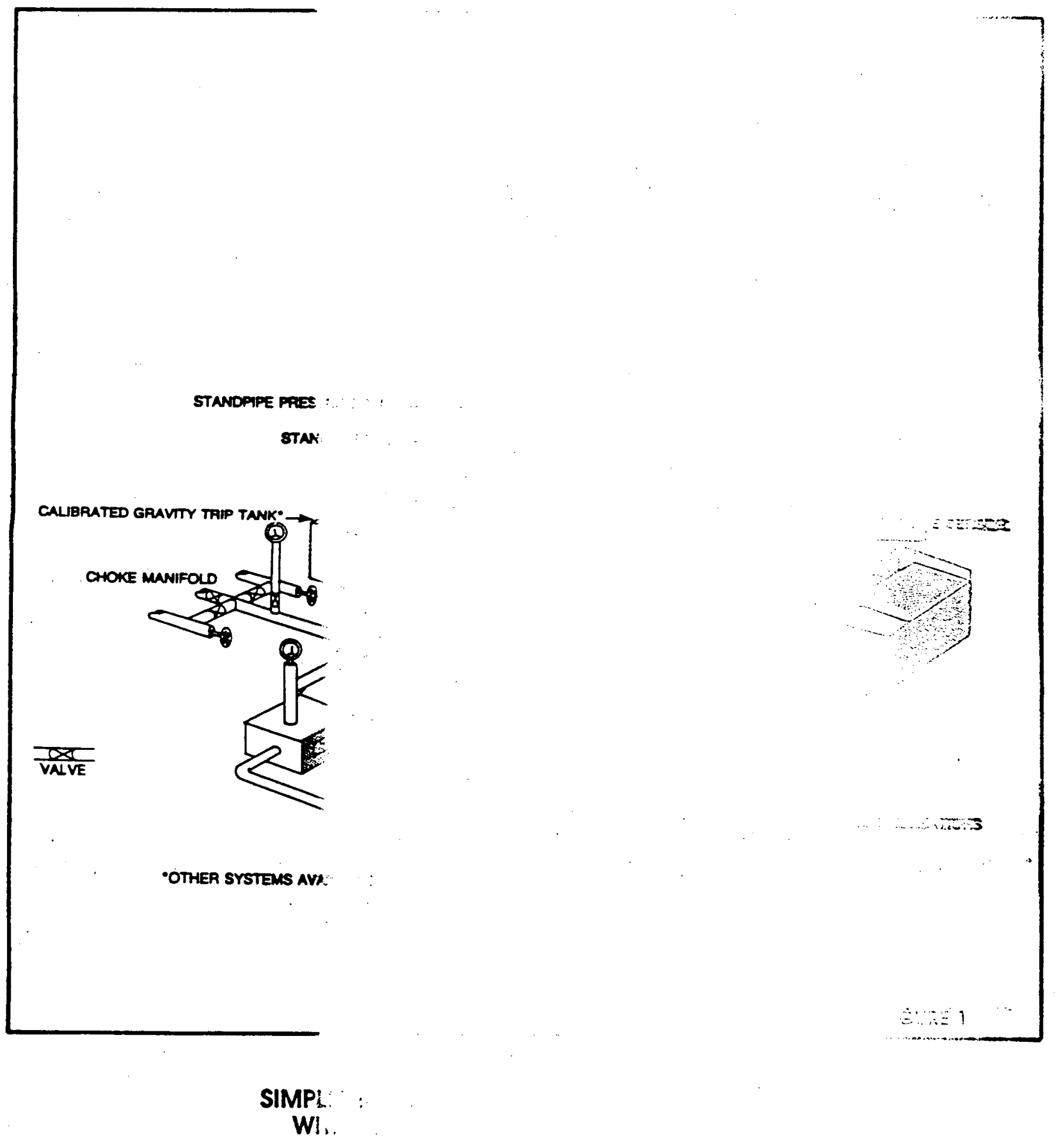

(Source: : 


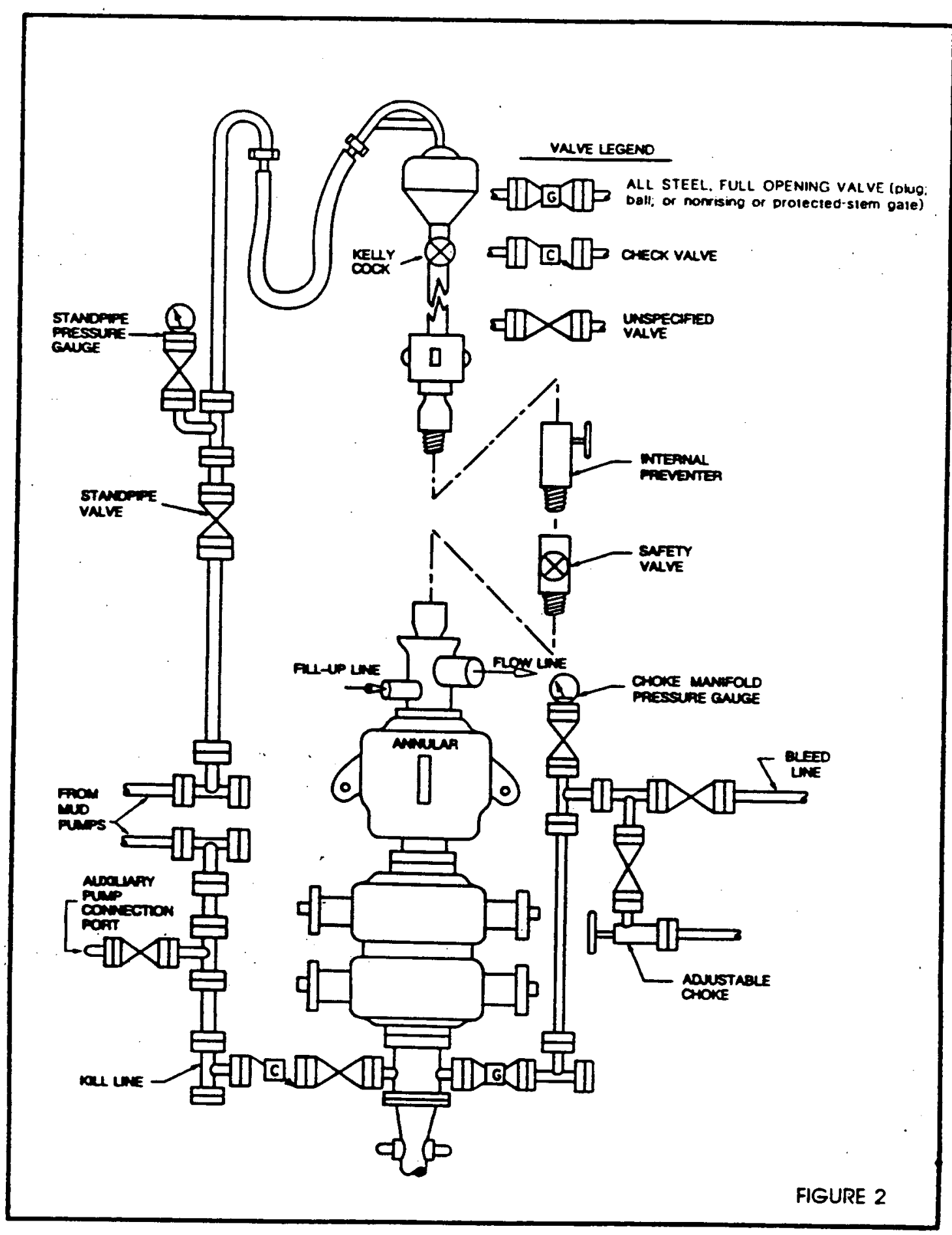

\section{SIMPLIFIED BOPE CONFIGURATION}

(Source: Modified from Blowout Prevention in California. 1987) 
- $\ldots$

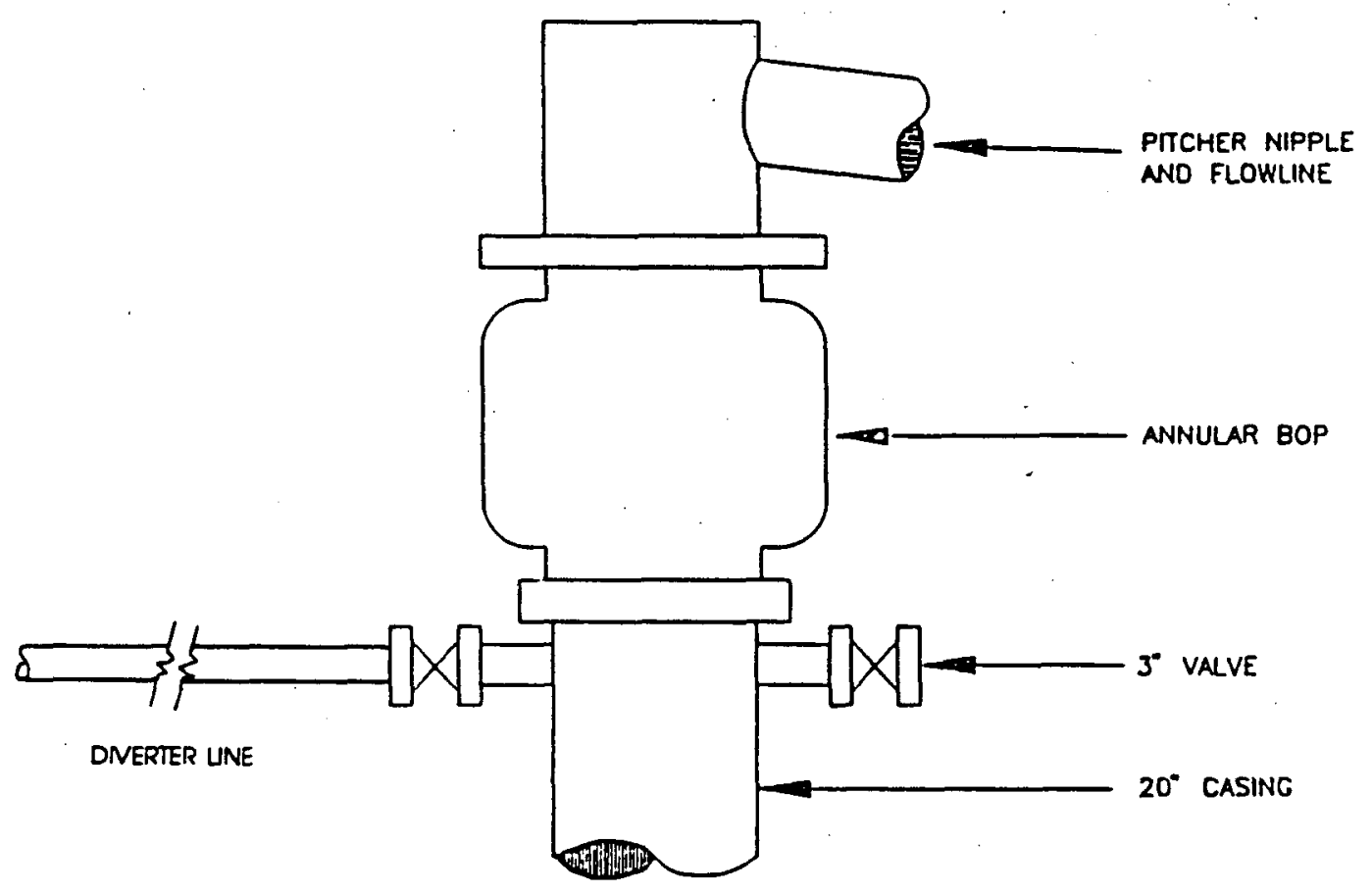

PUNA GEOTHERMAL VENTURE

$20^{\circ}$ BOP

CONFIGURATION

FIGURE 3

(Source: Modified from PGV Drilling Permit Application for KS-8, 1991) 


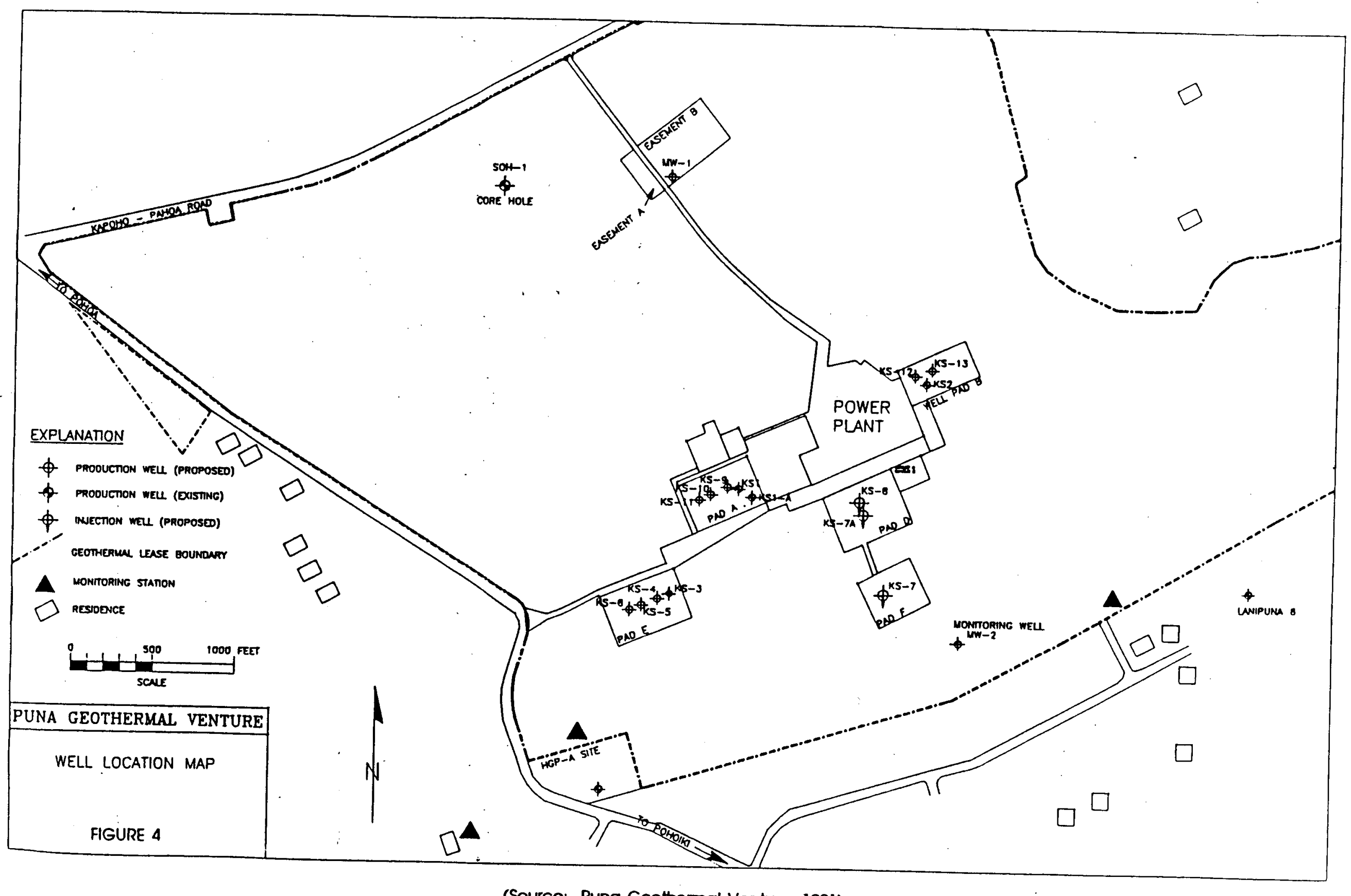

(Source: Puna Geothermal Venture, 1991) 


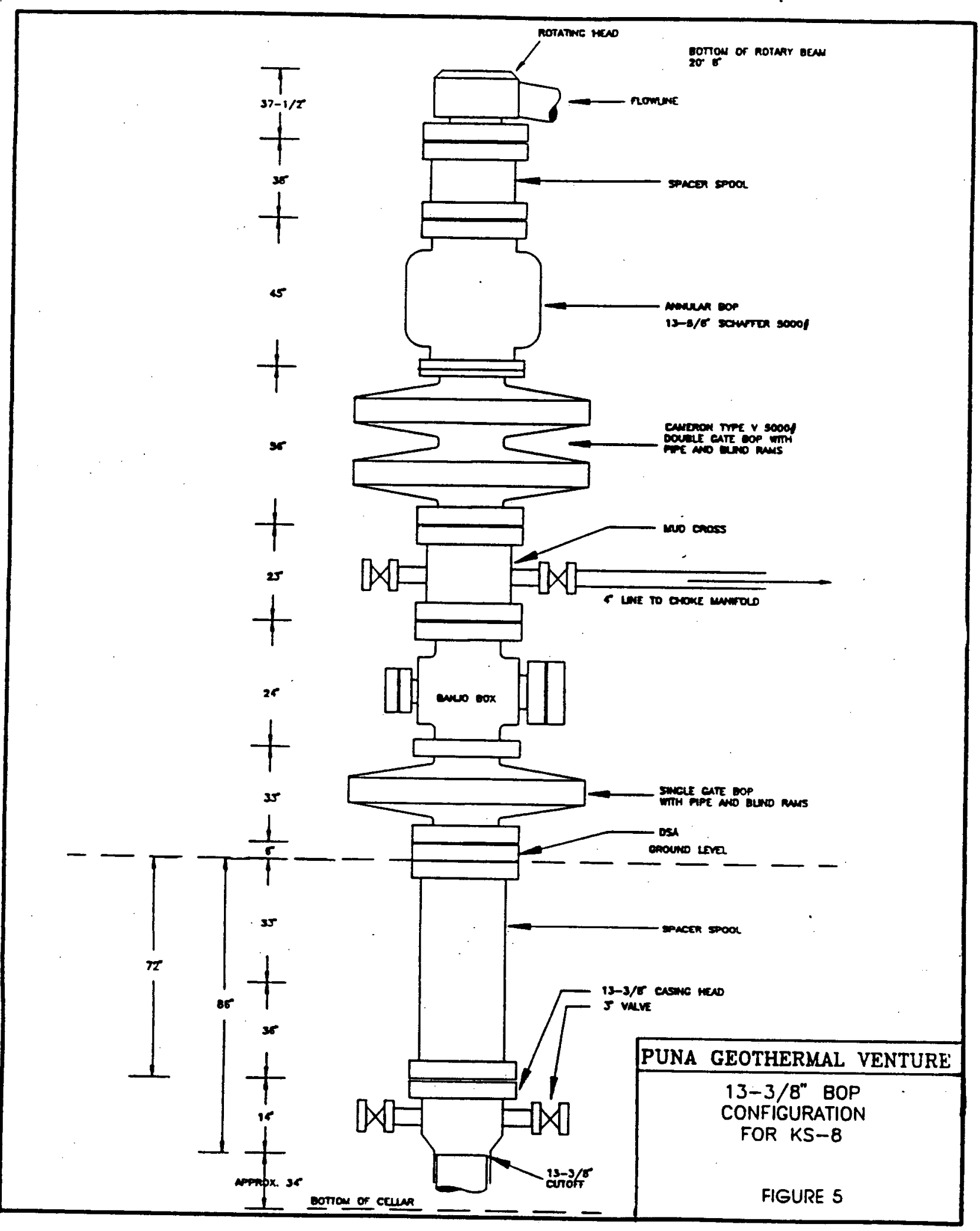

(Source: PGV Geothermal Well KS-8 Uncontrolled Flow Event and Well Design Review, 1991) 
. '. .

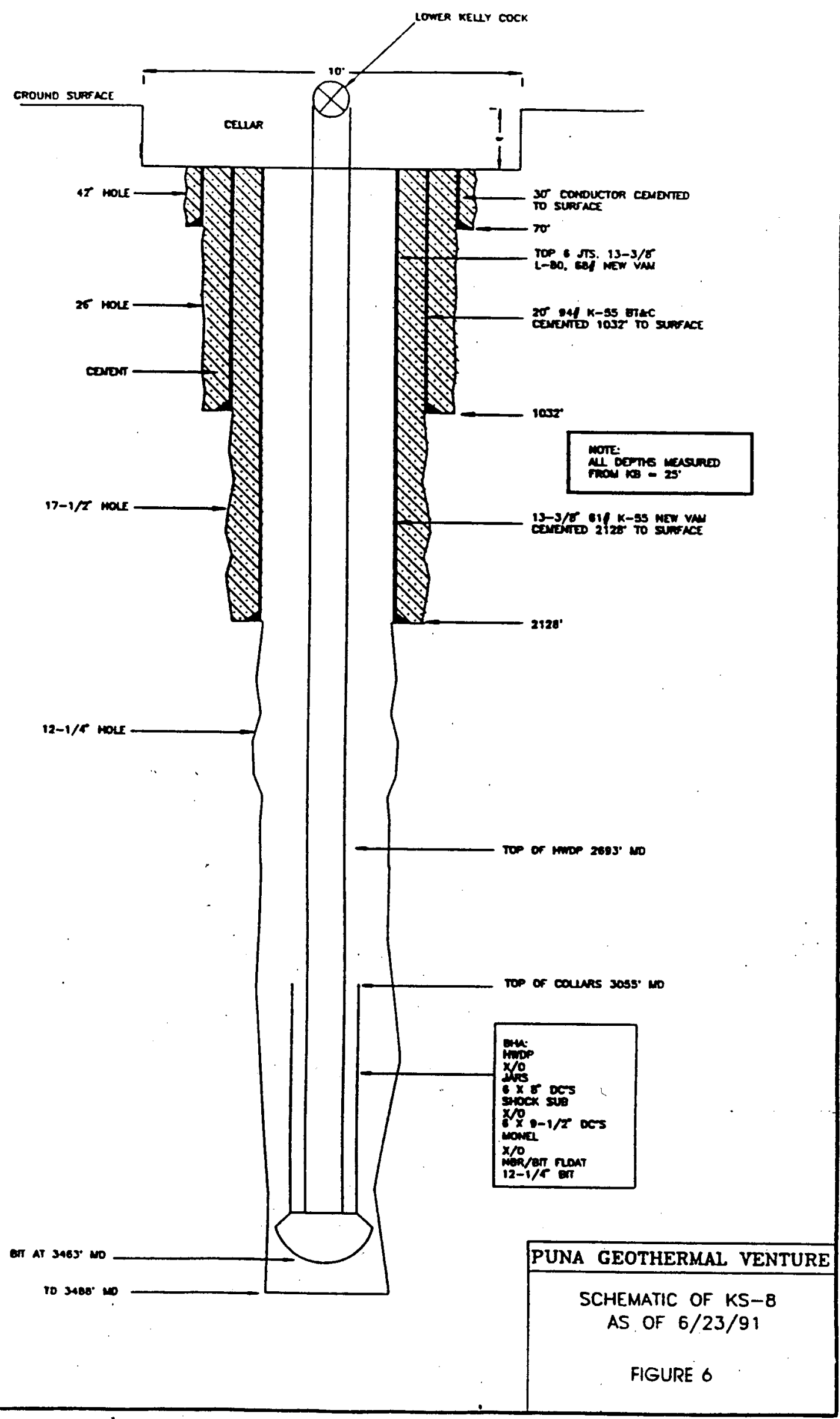

(Source: PGV Geothermal Well KS-8 Uncontrolled Flow Event and Well Design Review. 1991) A.6 


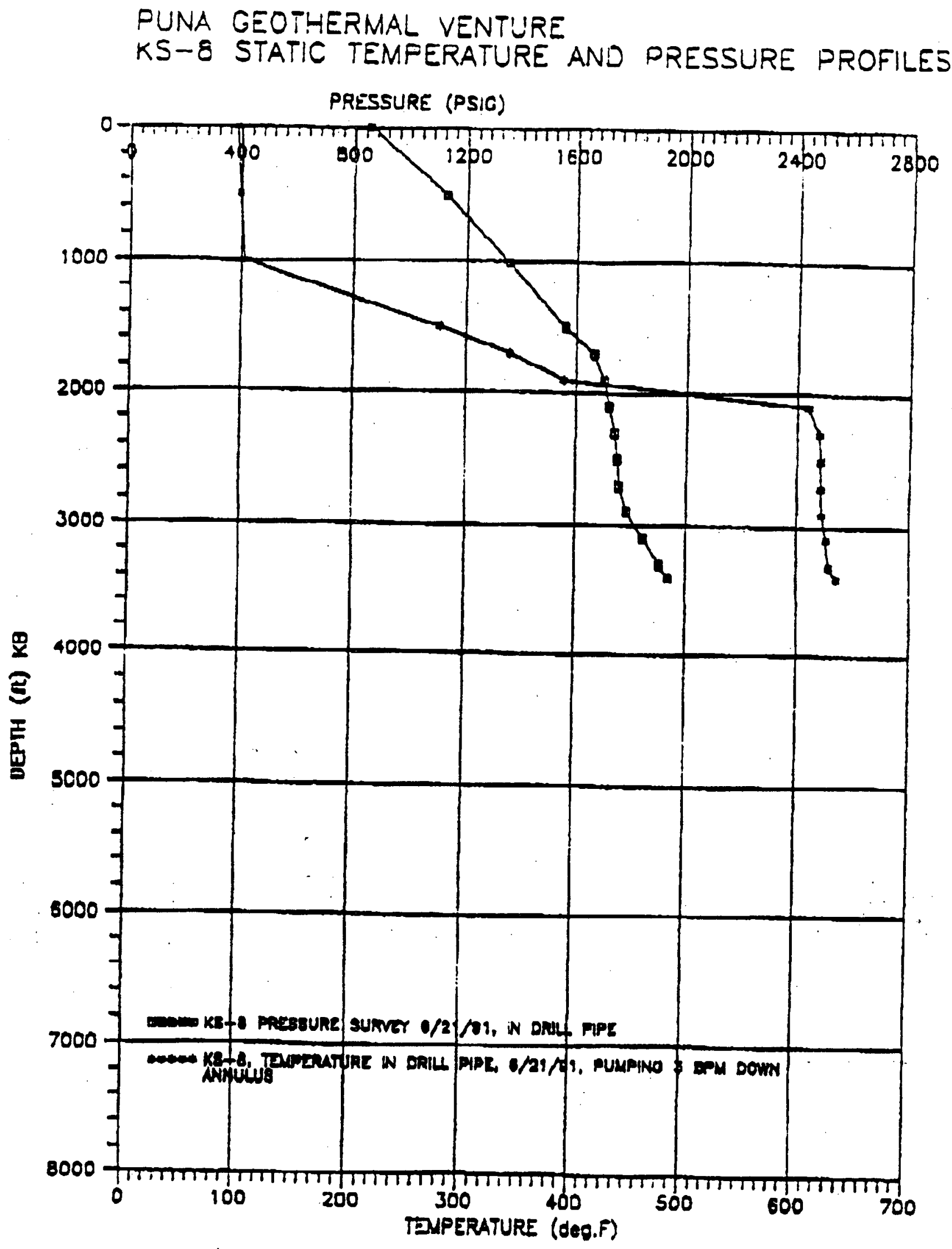

FIGURE 7

(Source: Puna Geothermal Venture, 1991) 


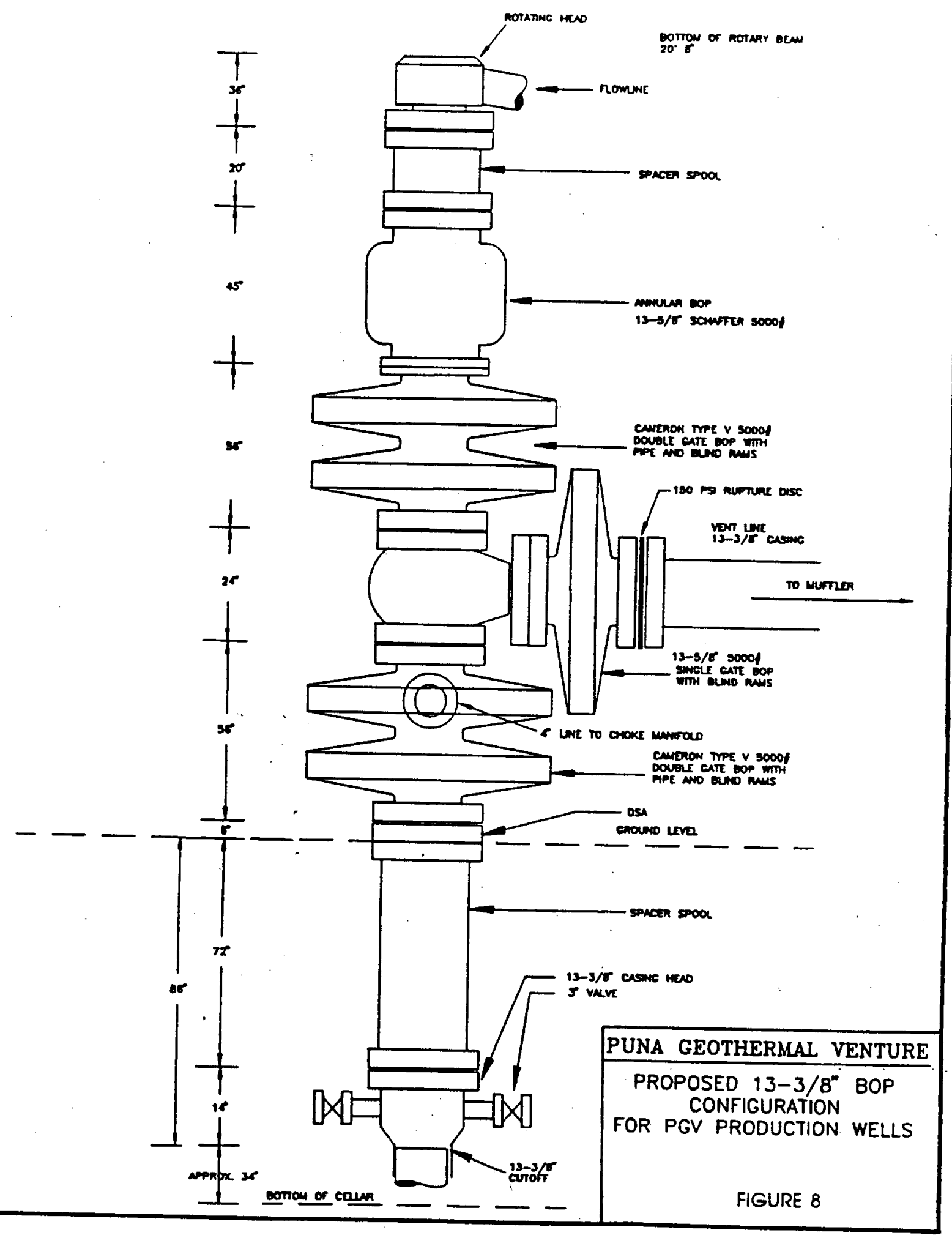

(Source: PGV Geothermal Well KS-8 Uncontrolled Flow Event and Well Design Review. 1991) 


\section{0* DIVERTER}

VENT WELL ABOVE TOP

OF RLOW MPPLE

VENT LNE SHOULD BE

CORRECTLY ORENTED

DOWNMHO FROM THE

RIG AND FACLUTIES

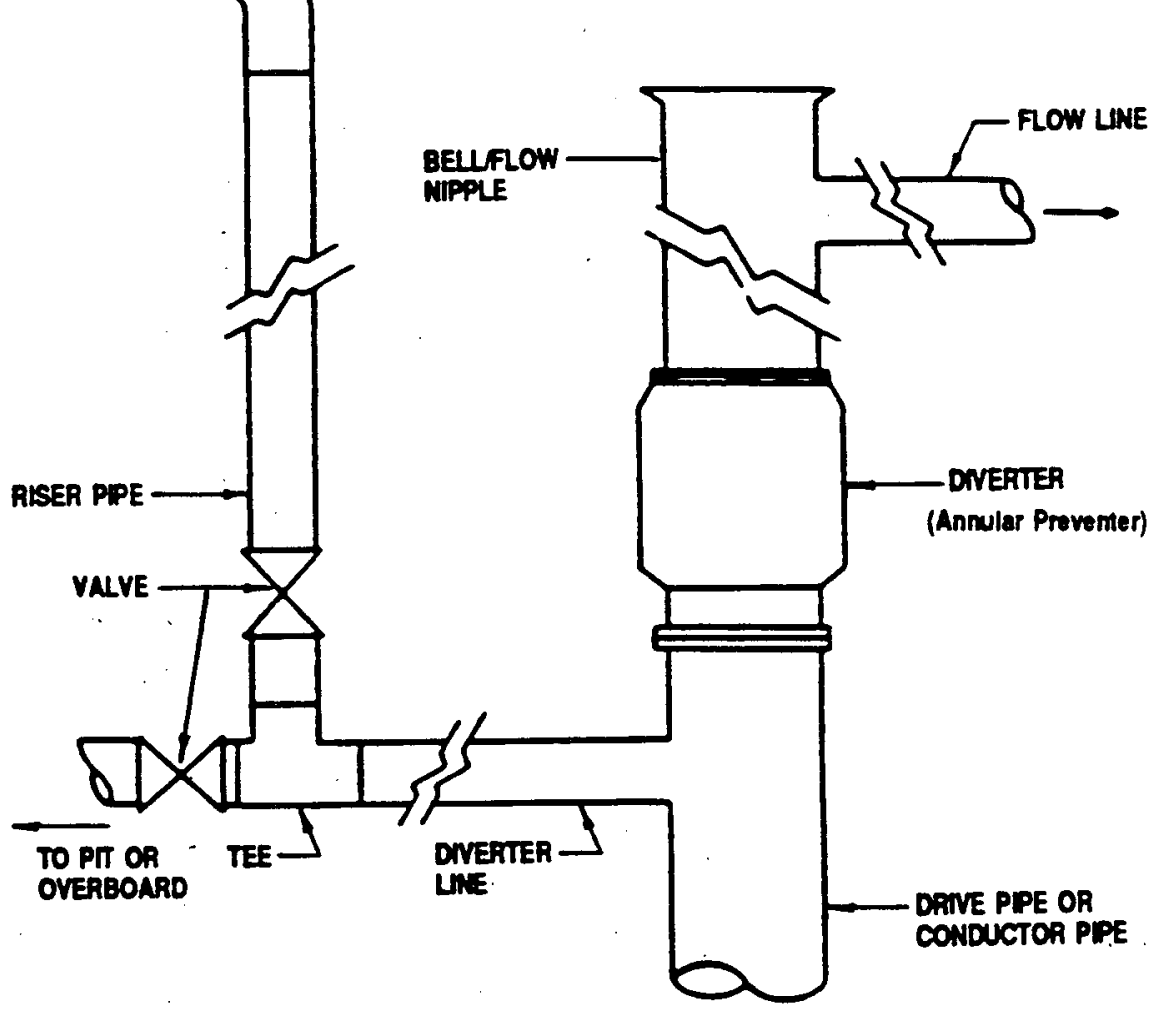

FIGURE 9

\section{SURFACE INSTALLATION, MANUAL SELECTIVE FLOW SYSTEM}

(Source: Modified from Blowout Prevention in Califomia. 1987) 


\section{0* B.O.P. STACK}

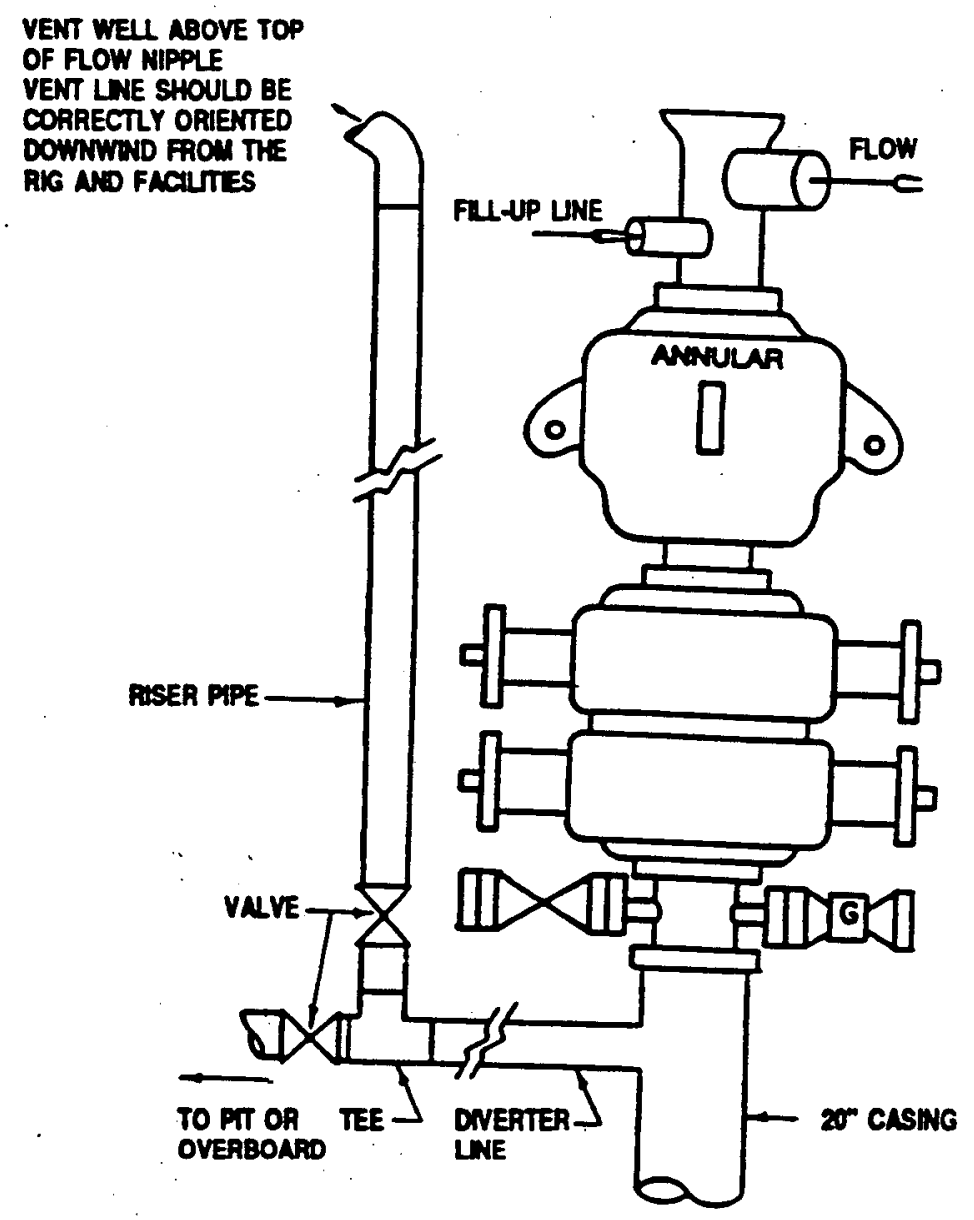

FIGURE 10

\section{SURFACE INSTALLATION, MANUAL SELECTIVE FLOW SYSTEM}

(Source: Modified from Blowout Prevention in Califomia, 1987) 
$\therefore$

APPENDIX B 
DRILLING HISTORY BETWEEN MAY 1, 1991 AND JUNE 6, 1991

05-01-91: $\quad$ Moved in and rigged up Parker Drilling Company rig \#231.

05-02-91: Rigged up for 3 hours, drilled rat hole for 8-1/2 hours with Eastman mud motor. Picked up 26-inch bit with mud motor, drilled from $35^{\prime}$ to $77^{\prime}$. Laid down 26-inch bit, picked up 42-inch hole opener.

05-03-91: Waited for 7 hours, from 12 midnight to 7:00 am because of noise complaints. Opened 26-inch hole to 42".

05-04-91: Continued opening hole from 26" to 42" to the depth of 77'. Laid down drilling tools (bottom hole assembly). Picked up 30-inch conductor pipe, landed on bottom, cemented conductor with 150 sacks of Hawaii cement. Welded on rotating head to 30 -inch conductor.

05-05-91: Continued installing rotating head and flow line. Picked up 26-inch drill bit, drilled from $74^{\circ}$ to $161^{\prime}$.

05-06-91: Continued drilling 26-inch hole, from $161^{\circ}$ to $253^{\circ}$. (Drilling with air.)

05-07-91: Drilled from $253^{\circ}$ to $297^{\circ}$, ran directional survey, drilled from $297^{\circ}$ to $390^{\circ}$, pulled out of hole, installed drilling jars, ran back to bottom of hole, drilled from $390^{\circ}$ to $422^{\prime}$. (Drilling with air and foam.)

05-08-91: Drilled from 422' to 573'. (Drilling with air and foam.)

05-09-91: Drilled from 573' to 630'. (Drilling with air and foam.) Pulled out of hole, and rigged up bailer on swab line and bailed water for 6 hours ( 44 samples or runs). Representative water sample taken for State authorities. Ran in hole with new bit \#2. Worked through tight spot in hole at $544^{\circ}$.

05-10-91: Washed and reamed from $605^{\circ}$ to $630^{\circ}, 25^{\circ}$ of cuttings (or fill). Drilled from $630^{\circ}$ to $734^{\circ}$. (Drilling with air and foam.)

05-11-91: Drilled from $734^{\circ}$ to $933^{\circ}$. (Drilling with air and foam.)

05-12-91: Drilled 26-inch hole from 933' to $1039^{\circ}$. Tripped out of hole, picked up reamer, ran in hole to $169^{\circ}$, washing and reaming hole to $347^{\circ}$. Shut down operation at 10:30 pm until 12 midnight because of noise complaint.

05-13-91: From 12 midnight to $6: 00$ am (6 hours), waited because of noise, ran in hole, continued reaming from $347^{\circ}$ to $867^{\circ}$ (reaming with air and foam).

05-14-91: Reamed from $867^{\circ}$ to $1039^{\prime}$, drilled new hole from $1039^{\circ}$ to $1049^{\circ}$, circulated hole with air and foam, pulled drill bit out of hole, rigged up to run 20-inch diameter casing and weld on shoe. 
05-15-91: Ran 26 joints of 20-inch casing and cemented same, 20-inch casing set at depth of $1032^{\circ}$. Waited on cement to set up.

05-16-91: Ran 1-inch pipe on back side to the depth of $767^{\circ}$, cemented with 170 sacks Hawaii cement. Pulled 1-inch pipe out, waited on cement, ran 1-inch pipe back to $767^{\circ}$, pumped 159 sacks of Hawaii cement, waited on cement.

05-17-91: Waited on cement, $\operatorname{ran}$ in hole with 1-inch pipe to $767^{\circ}$ pumped in 308 sacks Hawaii cement. Waited on cement, ran in with 1-inch pipe to top of cement at $780^{\circ}$. Cemented through 1 -inch pipe with 500 sacks of Hawaii cement, pulled out of hole, waited on cement, $\operatorname{ran}$ in hole with 1-inch pipe to top of cement at $300^{\circ}$. Cemented through 1-inch pipe with 500 sacks of Hawaii cement. Pulled out of hole, waited on cement, ran in hole to top of cement at $270^{\circ}$, cemented through 1 -inch pipe with 500 sacks of Hawaii cement, waited on cement. Cement at surface.

05-18-91: Cut off 20-inch casing, installed blow out prevention equipment which consisted of 1 Hydril and 1 rotating head. Laid down 26-inch drilling assembly, picked up 17-1/2-inch drilling assembly.

05-19-91: Cleaned cement out of Hydril, ran in hole. Tested casing, pumped away at $400 \mathrm{psi}$ into formation, no test results. Cut and slipped drilling line and pulled out of hole, ran back in hole to top of cement at $996^{\circ}$. Rigged up Halliburton, cemented inside of 20-inch casing with 120 sacks cement. Closed Hydril, squeezing cement into formation, pulled out of hole, picked up a Bottom 'Hole Assembly, ran in hole and tagged top of cement at $927^{\prime}$. Drilled out cement from $927^{\circ}$ to $1039^{\circ}$. Cleaned out to $1049^{\circ}$. Pulled out of hole, set back drilling assembly, ran back in hole open-ended to the depth of $1049^{\circ}$.

05-20-91: Rigged up Halliburton, pumped in 380 sacks of cement, pulled 3 stands of drill pipe, pumped 45 bbls of mud, could not fill the hole, tripped out, waited on cement. Tripped in, tagged cement at $844^{\circ}$, drilled out cement from $844^{\prime}$ to $1028^{\prime}$, closed Hydril, tested casing to 600 psi, held for 30 minutes.

05-21-91: Drilled cement from $1028^{\circ}$ to $1035^{\circ}$, tested formation by performing leak off test. Pumped into formation at 400 psi while pumping with rig pump. Installed rotating head. Drilled cement from $1035^{\circ}$ to $1049^{\circ}$, drilled from $1049^{\circ}$ to $1100^{\circ}$ into formation. Circulated, surveyed at $1060^{\circ}, 2-1 / 4$ degree, pulled out of hole, ran in hole open-ended. Rigged up Halliburton, pumped 129 sacks of Hawaii cement, pulled out of hole, $\operatorname{ran}$ in hole with drilling assembly to top of cement at $1008^{\circ}$. Drilled cement from $1008^{\circ}$ to $1055^{\circ}$, pulled out of hole with drilling assembly, ran back in hole open-ended. Rigged up Halliburton, pumped 105 sacks Hawaii cement. Closed Hydril, pumped 36 bbls of water at 500 psi and pulled out of hole. 
05-22-91: Tripped in hole to $828^{\circ}$, waited on cement for 5-1/2 hours. Ran in hole, tagged cement at $1031^{\circ}$, drilled cement from $1031^{\circ}$ to $1057^{\prime}$. Pressure tested formations. Cleaned mud pits, pulled out of hole, ran in hole open-ended, dropped stand of drill pipe in hole, picked up fishing tools, went in hole, retrieved stand of drill pipe. Ran back in hole to $1023^{\circ}$, rigged up Halliburton cemented with 211 sacks of Hawaii cement. Pulled 3 stands, closed Hydrill, pumped in 35 bbls of water. Shut in for 30 minutes at 800 psi. Pulled out of hole and waited on cement.

05-23-91: - Waited on cement, tripped in hole with drilling assembly, tagged top of cement at $812^{\circ}$, drilled out cement to $1050^{\circ}$, pressure tested formation to $100 \mathrm{psi}$, pressure fell to zero, did not hold. Drilled cement from $1050^{\circ}$ to $1100^{\circ}$. Drilled formation from $1100^{\circ}$ to $1150^{\circ}$. Pulled out of hole, tripped in hole open-ended to $1150^{\circ}$.

05-24-91: Rigged up Halliburton, and pumped 200 sacks of Hawaii cement, tripped out of hole, waited on cement for 5-1/2 hours, tripped in with drilling assembly to top of cement at $940^{\circ}$. Drilled cement from $940^{\circ}$ to $1150^{\circ}$, drilled formation from $1150^{\circ}$ to $1165^{\circ}$. Pulled bit up into casing and cleaned mud pits. Ran in hole, tagged fill at $1121^{\circ}$, cleaned out from $1121^{\circ}$ to $1165^{\circ}$, drilled new formation from $1165^{\prime}$ to $1287^{\prime}$.

05-25-91: Drilled from $1287^{\circ}$ to $1366^{\circ}$, surveyed, $1 / 2$ degree, continued drilling from $1366^{\prime}$ to $1386^{\prime}$, tripped out with drilling assembly, $\operatorname{ran}$ in hole open-ended, rigged up Halliburton, pumped 205 sacks of Hawaii cement. Pulled out of hole, waited on cement for 8-1/4 hours. Ran in hole with drilling assembly to top of cement at $1198^{\circ}$, drilled cement from $1198^{\prime}$ to $1334^{\circ}$.

05-26-91: Continued drilling cement from $1334^{\circ}$ to $1386^{\circ}$. Pulled out of hole with plugged bit, ran in hole with drilling assembly to $1289^{\circ}$, washed and reamed from $1289^{\circ}$ to $1386^{\circ}$, drilled new formation from $1386^{\circ}$ to $1549^{\circ}$. Pulled out of hole. Installed rotating head. Ran in hole open-ended, tagged fill at $1460^{\circ}$, washed out fill from $1460^{\circ}$ to $1549^{\circ}$. Rigged up Halliburton, pumped 220 sacks of Hawaii cement. Ran drilling assembly to $950^{\circ}$, installed rotating head, waited on cement 3-1/2 hours.

05-27-91: Ran in hole, tagged cement at $1367^{\circ}$, drilled cement from $1367^{\circ}$ to $1539^{\prime}$, no cement from $1539^{\circ}$ to $1549^{\circ}$. Pulled out of hole with plugged bit, unplugged bit, ran in hole with drilling assembly, tagged fill at $1412^{\circ}$, washed and reamed from $1412^{\circ}$ to $1549^{\circ}$, drilled new formation from $1549^{\circ}$ to $1612^{\prime}$, surveyed at $1550^{\circ}, 1-1 / 4$ degrees $S-85^{\circ}-W$, continued drilling from $1612^{\circ}$ to $1683^{\circ}$.

05-28-91: Drilled from $1683^{\circ}$ to $1859^{\circ}$, surveyed at $1820^{\circ}, 1-3 / 4$ degrees, $S-80^{\circ}-\mathrm{W}$, continued drilling to $2020^{\circ}$, tripped out of hole, $\operatorname{ran}$ in hole open-ended to $2020^{\circ}$, rigged up Halliburton, pumped 290 sacks of Hawaii cement, pulled out of hole, $\operatorname{ran}$ in hole with drilling assembly to $1000^{\circ}$. 
05-29-91: Waited on cement, $\operatorname{ran}$ in hole, tagged cement at $1848^{\circ}$, drilled cement from $1848^{\circ}$ to $2020^{\prime}$, drilled new formation from $2020^{\prime}$ to $2134^{\prime}$, tripped out of hole, rigged up to run 13-3/8-inch casing. Ran 13-3/8-inch casing.

05-30-91: Continued running 13-3/8-inch casing to the depth of $2128^{\circ}$. Rigged down casing crew, $\operatorname{ran}$ in hole with 5-inch drill pipe screwed into shoe. Rigged up Halliburton, cemented with 705 sacks of Hawaii cement. Pulled out of hole, waited on cement.

05-31-91: Continued waiting on cement. Cement fell $174^{\circ}$ in casing annulus, ran 1inch pipe, pumped 100 sacks of Hawaii cement. Waited on cement. Cut off 13-3/8-inch casing, welded on 13-3/8-inch well head (3000\#), preheated with HOT-head.

06-01-91: Continued welding on well head, installed 13-5/8-inch Blow Out Prevention Equipment. Tested Blow Out Prevention Equipment at 600 psi for 30 minutes. Ran in hole with drilling assembly to top of cement at 2073', pressure tested pipe rams, choke manifold, Hydril to 600 psi for 30 minutes.

06-02-91: Drilled cement from $2073^{\circ}$ to $2134^{\circ}$, drilled new formation from $2134^{\circ}$ to $2276^{\circ}$, surveyed at $2225^{\circ}, 3-1 / 4$ degrees, S-89 $-\mathrm{W}$. Pulled out of hole. Ran in hole with mud motor, attempted to orient mud motor, pulled out of hole, worked on mule shoe and bent sub.

06-03-91: Ran in hole, oriented mud motor, drilled 12-1/4-inch hole from $2276^{\circ}$ to $2347^{\prime}$. Blew out kelly hose, pulled 4 stands of drill pipe, installed new kelly hose, $\operatorname{ran}$ back in hole. Drilled and surveyed from $2347^{\circ}$ to $2598^{\circ}$.

06-04-91: Drilled and surveyed from 2598 to $2627^{\circ}$, tripped out of hole, laid down mud motor, picked up drilling assembly, $\operatorname{ran}$ in hole to $2270^{\circ}$, washed and reamed from $2270^{\prime}$ to $2627^{\circ}$. Drilled from $2627^{\circ}$ to $2641^{\prime}$, surveyed, pulled out of hole, picked up mud motor, ran in hole, oriented mud motor, drilled from $2641^{\circ}$ to $2689^{\prime}$.

06-05-91: Drilled and surveyed from $2689^{\circ}$ to $2934^{\circ}$, pulled out of hole, laid down mud motor, picked up drilling assembly, ran in hole, reamed from $2627^{\circ}$ to 2898.

06-06-91: Reamed from $2898^{\circ}$ to $2934^{\circ}$, drilled and surveyed from $2934^{\circ}$ to $3177^{\circ}$. 